\title{
UPACARA PITUNGDINO KEMATIAN DALAM PRAKTEK KEHIDUPAN PAGUYUBAN MAJAPAHID DAERAH KHUSUS IBUKOTA JAKARTA
}

\author{
Oleh: \\ Prianik \\ Pascasarjana Universitas Hindu Indonesia \\ Denpasar \\ pr_anik@yahoo.com
}

\begin{abstract}
Death is something that will definitely happen but cannot be sure when the death will come to someone. For Hindus, death is a process of soul journey to Paramatman. In order for the journey of Jiwatman to not occur, obstacles need to be helped with the execution of a death ceremony, one of the ceremonies of the death ceremony of Hindus in Java, namely the Pitungdino death ceremony. In carrying out the ceremony, did the members of the Majapahid Paguyupan who incidentally live in the Metropolitan capital still carry out?, where all members did not come from one area, but from various regions with different traditional backgrounds. The Pitungdno death ceremony is a Hindu teaching that has been carried out since our ancestors, and what benefits or benefits can be obtained in carrying out this ceremony? To answer that question this research was conducted. The Pitungdino death ceremony conducted by members of the Majapahid Association from one region to another is very different, this is the result of research in one of the villages of the Majapahid Circle of Friends, namely as follows: Pasrah pancen, enggeh / kenduren, and the Pitra event Puja.

The function of the pitungdino ceremony of death is as a prosecutor's process or a guide for Jiwatman to paramatman. This ceremony aims to improve the seven layers in the human body, namely muscle, flesh, blood, marrow, skin, bones and hair.

The benefit of the pitungdino death ceremony is for the offspring, if it is carried out which is aimed at dedication and our sincere devotion to our ancestors, raising and perfecting the position of the spirits of our ancestors in Swah Loka, and paying attention to the interests of parents in realizing devotion. This was carried out with the realization that as a descendant he had been indebted to his parents / ancestors (Pitra Rna). The benefits of this series of ceremonies are for children, grandchildren and their descendants, namely for welfare, and changes in the natural environment on a skala and niskala.
\end{abstract}

Keywords: Study, Didactic, Pitungdino Death Ceremony

\begin{abstract}
Abstrak
Kematian adalah sesuatu yang pasti akan terjadi tetapi tidak dapat dipastikan kapan akan datangnya kematian itu pada seseorang. Bagi umat Hindu kematian merupakan proses perjalanan jiwatman menuju Paramatman. Agar perjalan jiwatman tidak terjadi hambatan perlu di bantu dengan adanya pelaksanaan upacara kematian, salah satu pelaksanaan upacara kematian umat Hindu di Jawa yaitu upacara Pitungdino kematian. Pelaksanaan upacara Pitungdino kematian yang dilakukan oleh anggota Paguyuban Majapahid dari daerah satu dengan daerah yang lainnya sangat
\end{abstract}


berbeda beda. Fungsi dari pada upacara pitungdino kematian ini adalah sebagai proses penuntut atau penunjuk jalan bagi jiwatman menuju paramatman. Upacara ini bertujuan untuk proses penyempurnaan tujuh lapisan yang ada dalam tubuh manusia yaitu otot, daging, darah, sumsum, kulit, tulang dan rambut. Manfaat upacara pitungdino kematian ini bagi keturunannya, jika di laksanakan yaitu bertujuan untuk pengabdian dan rasa bhakti kita yang sangat tulus ikhlas kepada para leluhur kita, mengangkat serta menyempurnakan kedudukan arwah para leluhur kita di alam Swah Loka, dan memperhatikan kepentingan orang tua dalam mewujudkan rasa bhakti. Hal tersebut di laksanakan atas kesadaran bahwa sebagai keturunanya ia telah berhutang kepada Orang tua/ leluhur (Pitra Rna). Manfaat yang didapat dari rangkaian upacara tersebut untuk anak, cucu dan keturunanya yaitu untuk kesejahteraan, dan perubahan alam sekitar secara skala dan niskala.

Kata kunci: Kajian, Didaktis, Upacara Pitungdino kematian

\section{PENDAHULUAN}

Indonesia sangat multicultural dari berbagai jenis agama, suku dengan budayanya masingmasing yang sangat beragam, begitu juga dengan penganut agama Hindu di Indonesia sangat beragam suku dan budaya daerahnya masingmasing, dari sabang sampai meraoke semua agama Hindu menyebar di seluruh pelosok nusantara Indonesia. Salah satunya yaitu Agama Hindu dari Suku Jawa yang berasal di kepulauan Jawa. Dan saat ini Suku Jawa yang beragama Hindu tidak hanya diam di pulau Jawa saja tapi sudah menyebar keseluruh plosok penjuru Indonesia.

Sebagai wadah inspirasi umat Hindu khususnya suku Jawa dari berbagai daerah yang keluar dari daerah tanah kelahirannya untuk merantau menuju ibu kota Jakarta, maka di Jakarta terbentuk suatu komunitas yang bernama Paguyuban Majapahid.

Kita sebagai umat Hindu suku Jawa tidak pernah bisa lepas dariyang namanya bebantenan dan upacara keagamaan, kemanapun kita pergi atau tinggal kita tidak pernah bisa meninggalkan suatu kebiasaan yang sudah turun temurun kita lakoni/laksanakan. Masyarakat suku Jawa dikenal memiliki budaya yang sangat kental. Sampai era globalisasi saat ini pun adat istiadat masih kerap dijalankan dan ditaati oleh masyarakatnya. Upacara keagamaan sesuai dengan adat istiadat Hindu suku Jawa pun hampir terdapat di setiap momen kehidupan manusia. Semenjak dari kelahiran, perkawinan, hingga kematian memiliki tata cara sesuai dengan adat istiadat daerah masing-masing. Adat istiadat ini ialah sebuah budaya dan norma yang telah turun temurun dilakukan. Bahkan di dalam kehidupan bermasyarakat terdapat keharusan untuk melakukannya. Segala usaha akan dilakukan agar mereka bisa melaksanakan adat istiadat ini. Kebanyakan adat istiadat yang ada bersumber dari kepercayaan nenek moyang terdahulunya atau dari para leluhurnya.

Hindu adalah agama yang universal dan terbuka untuk seluruh umat manusia di dunia. Sebagai agama universal, tentunya Hindu akan menerima budaya apa saja yang sesuai dengan falsafah Hindu itu sendiri. Budaya itu akan mengalami akulturasi dengan Hindu sehingga membentuk suatu corak baru yang khas. Hal ini yang dapat menambah khasanah budaya dalam peradapan Hindu.

Tidak hanya suku Toraja dan Bali yang memiliki ritual kematian, suku Jawa pun juga memiliki ritual kematian. Ketika salah satu masyarakat suku Jawa meninggal dunia, ritual adat istiadat pun tak lepas mengiringi, salah satunya yaitu upacara pitungdino kematian (Pitra Yadnya). Upacara pitungdino kematian ini di lakukan pada saat tujuh hari setelah hari meninggalnya orang tersebut.

Yang tergabung dalam komunitas Paguyuban Majapahid berasal dari berbagai daerah yang beragama Hindu baik dari suku Jawa maupun suku-suku yang lainnya, pasti dalam pelaksanaan upacara nya pun juga bervariasi sesuai dengan ciri khas daerah masing-masing. Untuk itu dalam komunitas Paguyupan Majapahid inilah menjadi satu wadah dimana dalam pelaksanaan upacara pitungdino kematian ini kekompakan dan pelestarian budaya leluhur harus tetap tersemat walau berasal dari daerah yang berbeda-beda. 


\section{PEMBAHASAN}

\subsection{Pitungdino Kematian}

Upacara pitungdino kematian merupakan bagian dari runtutan upacara Pitra Yadnya secara adat Hindu Jawa, upacara ini dilakukan yaitu untuk mendoakan proses penyempurnaan tujuh lapisan/unsur yang terdapat dalam badan manusia yaitu, daging, otot, darah, kulit, tulang, sumsum, dan bulu. Yaitu dari alam Bhur sampai alam Sapta Loka/Sapto Patolo. Kalo di Jawa itu alam Eko Krudo yaitu meminta maaf jika yang meninggal mempunyai kesalahan. Jika di dalam alam Makrokosmos yaitu alam eko krodo, dwi karana, tri bhawana, catur mahendro, panca mertani, dwi jati, wasto karana (alam fitri/alam kesucian). Yang harus di lewati oleh atman untuk menyatu dengan Brahman. Tetapi semua upacara ini juga berdasarkan Desa kala Patra, jadi setiap daerah mempunyai cara yang berbeda-beda sesuai dengan adat masingmasing daerah yang dipercayainnya. Upacara pitungdino berjumlah tujuh. Tujuh di kurang tiga, di kurang tiga, sisa satu. Tiga ini di artikan sebagai Tri Murti (Brahma Wisnu Siwa), lamuteng bopo biyung lamuteng sing agawe urip sisa satu yaitu artinya satu adalah jagat raya ini dan bahwa jagat itu hanya satu. (wawancara, Romo Rsi Adhyaksa, Blitar Januari,18, 2019)

Seperti di uraikan dalam kitab Brhad Aranyaka Upanisad, Bab VI. 2.16 adalah sebagai berikut :

Atha trayo vava lokah, manusya-lokah, pitr-loka, deva-loka iti. So'yam manusyalokah putrenaiva jayyah, nanyena karmana. Karmana pitr-loka, vidyaya deva-lokah. Deva-loko vai lokanam stresthah: tasmad vidyam prasamsanti.

\section{Artinya:}

Sekarang sesungguhnya ada tiga dunia yaitu, dunia manusia, dunia leluhur dan dunia dewata. Dunia manusia ini hanya bisa diperoleh melalui keturunan saja, bukan oleh perbuatan yang lain, dunia leluhur dengan persembahan, dunia para dewata dengan pengetahuan. Dunia para dewata adalah sesungguhnya dunia yang terbaik. Karena itulah mereka memuji pengetahuan. (Radhakrisna, Upanisadupanisad Utama 2015, 131)
Dari sloka di atas sudah sangat jelas bahwa dengan cara melakukan persembahan kepada para leluhur kita maka kita akan selalu terhubung, sebagaimana dalam ajaran Agama Hindu bahwa mulai kita di lahirkan menjadi manusia kita sudah membawa tiga hutang/Tri Rna. Salah satu dari tiga hutang tersebut adalah kita mempunyai hutang kepada para leluhur kita. Salah satu cara umat Hindu Jawa dalam membayar hutang kepada leluhur kita yang sudah meninggal yaitu melakukan prosesi upacara/slametan Pitungdino kematian

Pelaksanaan upacara pitungdino kematian ini biasanya dilaksanakan di rumah duka dengan mengundang umat Hindu satu Dusun dengan keluarga orang yang meninggal. Ini merupakan malam terahkir yang sebelumnya selama lima malam berturut-turut semenjak upacara telungdino.

\subsection{Pelaksanaan Upacara Pitungdino Kematian}

Dalam suatu prosesi pelaksanaan upacara Pitra Yadnya dari satu daerah dengan daerah yang lain pasti berbeda-beda sesuai desa kala patra. Sama seperti halnya dalam pelaksanaan upacara Pitungdino kematian ini, dimana dalam pelaksanaan upacara pitungdino kematian ini dalam anggota Paguyupan Majapahid dari daerah satu dengan yang lainya pasti banyak perbedaannya. Mulai dari perlengkapan upacara hingga cara dalam pelaksanaanya daerah satu dengan yang lainnya pasti berbeda sesuai dengan desa kala patra. (wawancara, Eko, februari,20, 2019).

Dalam hal ini akan penulis uraikan tentang upacara Pitungdino kematian yang pelaksanaanya di ambil di salah satu desa anggota Paguyuban Majapahid, yaitu di Dusun Sawur. Desa Bulusari, kecamatan Tarokan Kabupaten Kediri, Jawa Timur. sebagai berikut pelaksanaannya :

1. Masrahne pancen yaitu menghaturkan makanan dan minuman ada tiga gelas yaitu teh, kopi dan air putih berisi kembang telon. Tempat pancen ini di letakan di atas meja kecil di dalam senthong tengah.(kamar tengah).

2. Enggeh-enggeh/Kenduri yaitu untuk mendoakan yang meninggal supaya proses penyempurnaan dan perjalanan sang roh berjalan lancar untuk bersatu 
dengan Brahman/Sang Hyang Widhi Wasa. .

3. Pitra Puja. dilakukan pada malam hari dan dilakukan setiap malam semenjak upacara selametan telongdino. acara ini melakukan persembahyangan dan kekidungan Jawa, untuk mendoakan yang sudah meninggal.

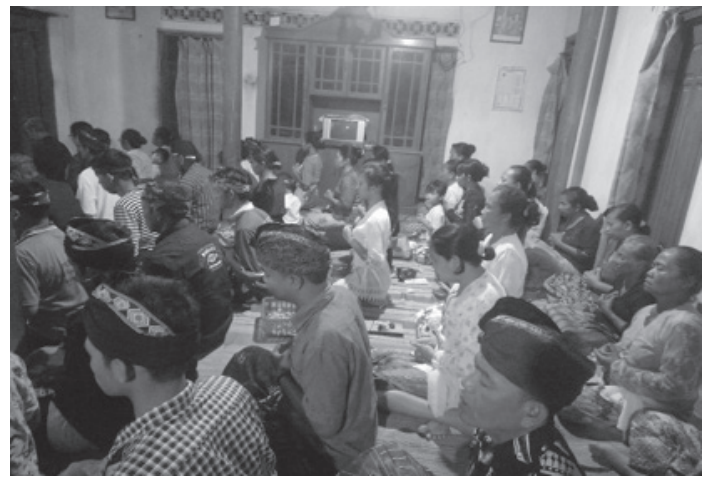

Gambar Acara persembahyangan Pitra Puja

4. Penutupan/ Parama shanti, di lanjutkan degan melekan yaitu berjagra tidak tidur semalem suntuk, bersama keluarga yang berduka.

\subsection{Banten Upacara/Prosesi Pitungdino} Kematin.

1. Banten ambengan yaitu nasi berbentuk brok/penek di lengkapi dengan lauk pauknya, mulai dari ayam kampung, pisang, apem dan lain-lainnya. Arti dari Ambengan nasi Brok ini adalah untuk persembahan ke pertiwi, selamatan ini bertujuan untuk memohon ijin kepada ibu pertiwi bahwa akan menempati tanah tersebut. (wawancara romo Adhyaksa, januari,18. 2019).

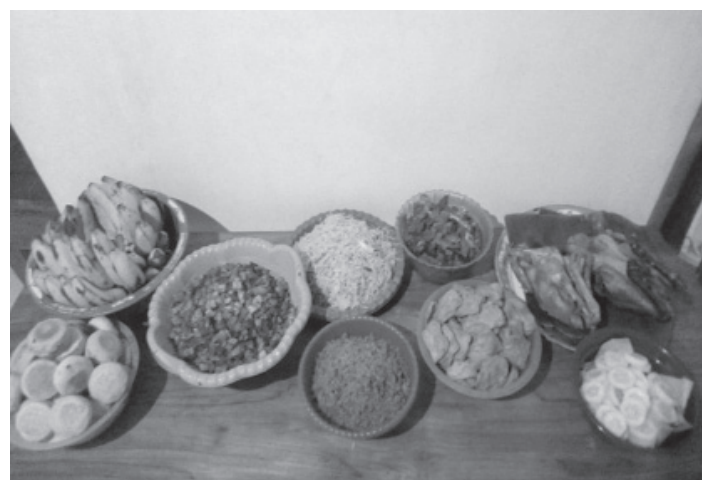

Gambar Ambengan
2. Banten di meja pemangku yaitu : Pejati satu set, satu besek sego suci ulam sari, jajan pasar, satu lepek jenang padang lepas (bubur kuning putih), jenang pitara yaitu bubur putih di atasnya diisi suket glinting dan kacang ijo.

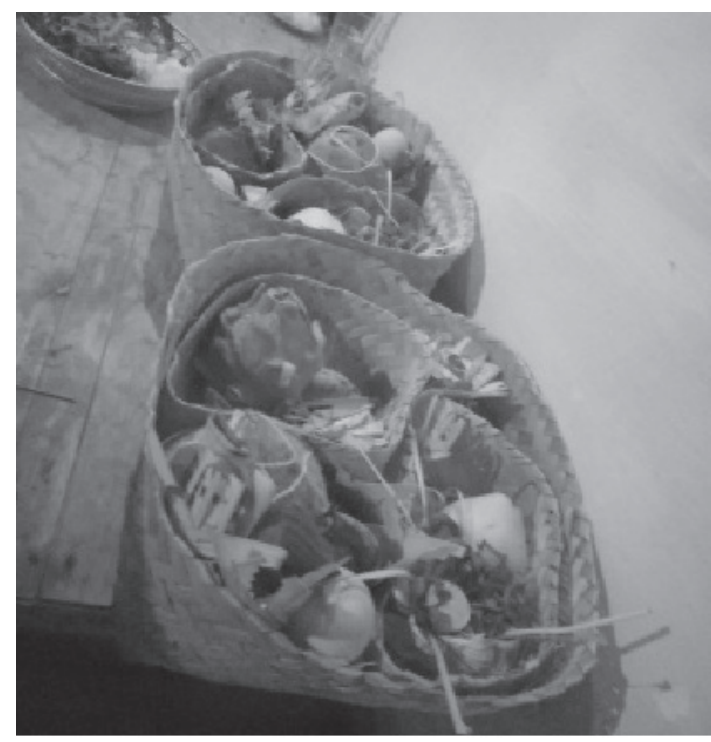

Gambar haturan depan pemangku

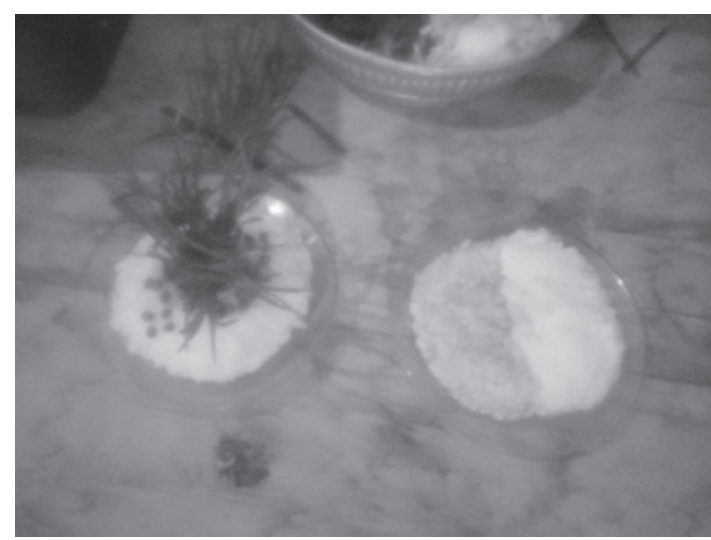

Gambar Jenang Pitara

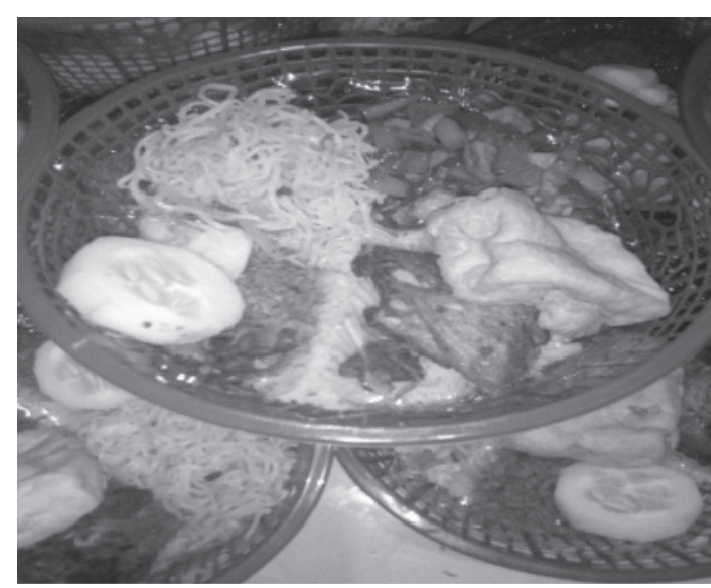

Gambar Sego suci ulam sari 
3. Kopi, teh, toyo kembang telon yaitu segelas air putih berisi bunga 3 warna). Banten inindi letakkan di senthong Tengah beserta makanan dan kue-kue kesukaan yang meninnggal.

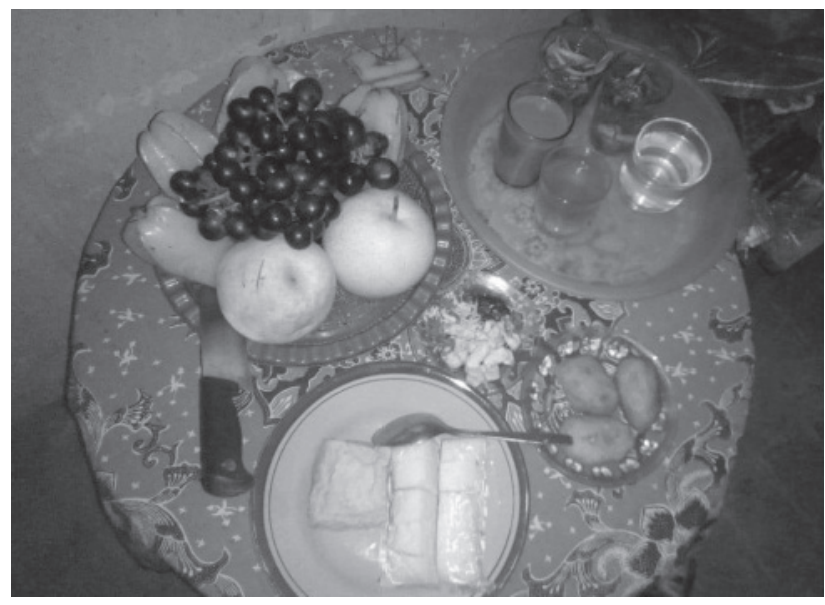

Gambar Pancen senthong tengah

\subsection{Kematian}

Secara umum kematian adalah akhir dari kehidupan, ketiadaan nyawa dalam organisasi biologis. Semua makhluk hidup pada akhirnya akan mati secara permanen, baik karena penyebab alami atau karena penyebab tidak alami. Atau suatu hal yang pasti dialami oleh semua makhluk hidup tanpa terkecuali. Karena semua makhluk hidup akan mengalami kematian, pandangan kematian itu sendiri sangat beragam di berbagai tempat. Pandangan tentang kematian yang berbeda-beda di tiap daerah akan menghasilkan cara yang berbeda pula dalam memaknai kematian tersebut. Satu hal yang perlu diingat pula adalah ternyata semua manusia di daerah manapun memiliki kesamaan persepsi tentang roda kehidupan yaitu manusia itu mengalami lahir, hidup dan akhirnya mati tanpa dapat diduga-duga.

Manusia tidak bisa lepas dari hukum alam (Rta) yang mengatur seperti lahir, hidup dan mati itu merupakan sudah menjadi kodrat manusia. Kematian merupakan suatu hal yang pasti ada dalam kehidupan setiap manusia. Kematian dalam agama Hindu di analogikan seperti orang yang mengganti pakaiannya yang lama artinya tidak layak digantikan dengan pakaian yang baru, badan jasmani punya batas/ masa waktu hidup badan-badan itu dengan sendirinya akan rusak, dan sang jiwa akan pindah ke badan yang lain. Seperti yang di uraikan oleh kitab Bhagawad Gita II.22 sebagai berikut:

Vasamsi jirnani yatha vihaya, navani grhanait naro parani

Tatha sarirani vihaya jirnany, anyani samyati navani dehi.

\section{Artinya:}

Seperti halnya orang menanggalkan pakaian usang yang telah dipakai dan menggantikanya dengan yang baru. Demikian pula halnya jiwatman meninggalkan badan lamanya dan memasuki jasmani yang baru. (Bhagawadgita, Pudja 2005 : 44-45)

Secara medis kematian adalah tidak berfungsinya organ tubuh yaitu jantung, batang otak, otak dan seluruh sel-sel di dalam tubuh. Secara Tattwa di jelaskan dalam kitab Wrspati Tattwa yaitu mati adalah berpisahnya Atman (Purusa) dengan Panca Maha Bhuta (Pradana dan Prakerti). Yang mati adalah badan yang rusak dan kembali kepada Panca Maha Bhuta, sedangkan Atman itu abadi. Dan secara upacara yaitu terurai dalam Lontar Wong Pejah yaitu menguraikan tentang kematian dianggap sah bila telah dilakukan upacara kematian. Sejak tata cara pemandian jenasah sampai mapegat. Setelah ini barulah keluarga dianggap cuntaka. (Wawancara, Pemangku Gusti Ngurah Rai, 2018)

Juga di uraikan dalam kitab kitab Bhawad Gita II.27 tentang kematian adalah suatu hal yang pasti dan semua orang pasti mengalaminya, yaitu sebagai berikut:

Jatasya Hi Dhruwo Mrityur, Dhruwam Janmamritasya Ca,

Tasmad Apariharye Rthe Na Twam Socitum Arhasi (Bhagawad Gita. Pudja 2005:48)

\section{Artinya:}

Sesungguhnya setiap yang lahir, kematian adalah pasti, demikian pula setiap yang mati kelahiran adalah pasti, dan ini tak terelakkan; karena itu tidak ada alasan engkau merasa menyesal.

Kematian adalah pasti bagi yang hidup. Bagaimana menghadapi kematian usahakan untuk senantiasa berkarma baik dan melakukan smaranam selalu menyebut dan mengagungkan 
nama Tuhan dengan mengucapkan Om. Bila hal ini terjadi pada orang lain baik itu orang tua saudara atau siapa saja saat menjelang meninggalnya dampingi dan bisikan $\mathrm{Om}$ pada telinganya sehingga akan mampu menuntun pada penyatuan rohnya dengan Sang Hyang Widhi. (Wawancara, Pemangku Gusti Ngurah Rai, 2018)

Om ity ekaksarambrahma, wyaharam mam anusamara,

Yah prayati tyajan deham, sa yati paramam gatim.(Bhagawad Gita.VII.13)

\section{Artinya:}

Ia yang mengucapkan $\mathrm{Om}$ aksara tunggal yaitu Brahman, dan mengingat Aku sewaktu ajal akan meninggalkan badan jasmani, ia akan pergi menuju tempat yang tertinggi (Moksa).

Dalam pupuh Kakawin Niti Sastra juga di jabarkan tentang kematian itu, yaitu sebagai berikut :

Kunang I datengnya ng mreta tepet ambek,

Atutura ring yoga tayanging atma.

Taki-takepadaki toson pakekesa sang wruh,

Wekasanikang tan hana juga toson.

\section{Artinya:}

Seandainya sang maut sudah menjeput, keteguhan hati kita harus tetap terpagut. Raihlah kesadaran melalui yoga tentang kelepasan jiwa. Segera berlatihlah dan lakukan hal itu dengan berguru kepada mereka yang tahu. Mengingat pada akhir waktu kita tidak ada yang bisa kita lakukan. (Kakawin Niti Sastra XIV.2)

Pupuh di atas senada dengan Canakya Nitisastra XII.12 yang menyatakan sebagai berikut :

Anityani sarirani wibhawo naiwa saswatah.

Nityam samnihito mrtyuh kartawyo dharma-samgrahah.

\section{Artinya:}

Tubuh ini tidaklah kekal, dan kekayaan kita sama sekali tidak abadi dan hanya kematianlah yang semakin mendekat.
Oleh karena itu kita sadarlah dan kembalilah ke jalan Dharma.

Sloka dan pupuh tersebut di atas sesungguhnya mengingatkan kepada kita semua bahwa hidup kita di dunia yang fana ini tidaklah kekal. Setiap manusia pada saatnya nanti akan mendapatkan ajal. Seiring dengan bergantinya sang waktu ajal bukannya semakin menjauh, dan itulah yang dinamakan dengan kematian bagi raganya tetapi bukan bagi atmannya. Jika saat hidup dia banyak melakukan dosa maka sang atman tersebut tidak akan pernah mendapatkan kebebasan dan kebahagiaan yang kekal. Oleh karena itu saat hidup di dunia adalah saat yang tepat bagi manusia untuk menghindari dosa tersebut dengan senantiasa berpegang teguh pada ajaran-ajaran dharma (kebenaran). Saat itu adalah saat dimana manusia akan dihadapkan dengan berbagai macam cobaan dan manusia harus dapat menolong dirinya sendiri. Jika ia lulus dari cobaan-cobaan tersebut maka ia akan dapat menolong dirinya sendiri dari lautan samsara atau reinkarnasi. Hal ini sebagaimana disebutkan dalam kitab Sarasamuscaya sloka 4 sebagai berikut:

Apan iking dadi wwang, utama juga ya, nimittaning mangkana,

Wenang ya tumulung sakeng sangsara, makasadhanang subhakarma, Hinganing kottamaning dadi wwang ika.

\section{Artinya:}

Menjelma menjadi manusia itu adalah sungguh-sungguh utama; sebabnya demikian, karena ia dapat menolong dirinya dari keadaan sengsara (lahir dan mati berulang-ulang) dengan jalan berbuatbaik, demikianlah keuntungannya dapat menjelma menjadi manusia. (Kakawin Niti Sastra, Miswanto, 2015)

Menyimak hal tersebut maka sudah seharusnya manusia sadar tentang siapa dia, darimana dia berasal, dan kemana dia akan kembali setelah mati nantinya. Jika hal tersebut sudah dipahami oleh seorang manusia maka ia tidak akan menjelma kembali ke dunia. Sebaliknya ia akan menyatu dengan Brahman. Hal ini sebagaimana diamanatkan dalam sebuah Tembang Dandanggula sebagai berikut:

Kawruhana sajatining urip, manungseku urip 
aneng donya, prasasat mung mampir ngombe, umpama paksi mabur, oncat saking kurungan neki, pundi pencokan mbenjang, ywa kongsi kaliru, umpama wong lunga Sonja, njan sinanjan tan wurunga bakal mulih, mulih mula mulanya.

\section{Artinya:}

Ketahuilah tentang hakekat hidup. Bahwa manusia hidup di dunia ini; dapat diibaratkan seperti orang yang singgah untuk minum; bagaikan burung terbang; yang keluar dari sarangnya; kemana dia harus hinggap maka janganlah sampai keliru; jika diibaratkan seperti orang yang pergi bertamu ke rumah tetagga, maka tak akan lama pun dia akan pulang, pulang kembali ke asalnya. (Kakawin Niti Sastra, Miswanto, 2015)

Untuk memahami hakekat hidup tersebut maka kita perlu merealisasikan kesadaran diri manusia menjaganya secara terus menerus. Meminjam filosofi Ignatius Suharyo, bahwa hidup itu perlu neng (meneng) supaya ning (wening) dan akhirnya nung (dunung). Artinya dengan meneng (diam) seseorang bisa menjadi wening (jernih hati dan pikirannya) agar lebih mampu memahami realitas hidup dalam hubungannya dengan diri sendiri, sesama, alam semesta dan Tuhan. Dan akhirnya kita bisa menjadi dunung (mengerti), maksudnya mampu membedakan mana hal-hal yang baik dan bermanfaat serta mana hal-hal yang tidak baik dan tidak bermanfaat. (Kakawin Niti Sastra, Miswanto, 2015).

\subsection{Upacara Atau Prosesi Kematian Hindu Di Jawa}

Masyarakat Hindu Jawa sangat menyakini bahwa kematian atau mati, orang Jawa mengatakan dengan istilah sedo atau tinggal donya adalah awal dari kehidupan selanjutnya. Mereka yang telah mati sebenarnya masih hidup hanya saja kehidupan yang dialami berbeda dengan dunia yang empiris ini. Manusia dalam kultur Jawa terdiri dari kesatuan tubuh dan nyawa. Kematian yang di yakini adalah terpisahnya antara nyawa dan tubuh yaitu mlesate jiwo/roh metu soko njero rogo. Tubuh adalah materi yang dapat di hancurkan sedangkan nyawa adalah unsur rohani yang tidak dapat di binasa. Unsur rohani inilah yang tetap hidup melanjutkan perjalanan menuju alam keabadian (Moksa).

Meluli keyakinan hidup abadi ini masyarakat Jawa melakukan ritual-ritual untuk mengiringi kembalinya roh ke dunia abadi dan hancurnya badan yaitu menjadi empat zat pokok yaitu air, tanah, udara dan api. Iringan ritual ini dilakukan dalam aturan waktu tertentu yaitu ritual upacara tiga hari, tujuh hari, empat puluh hari, seratus hari, setahun, pendak pisan, pendak pindo, seribu hari, dan Pangentas. Setelah ritual keseribu hari ini orang Jawa menyakini bahwa tubuh telah hancur dan roh telah kembali kealam keabadian (Moksa).

Budaya Jawa sangat menyakini bahwa kebahagiaan abadi adalah bersatunya roh dengan sang penciptanya. Oleh karena itu dalam segala bentuk mati raga dan menjauhkan diri dari hal-hal jelek selama manusia hidup sangat lumrah untuk dilakukan. Bahkan ketika manusia sudah mati sanak keluarganya membnatu dengan ritual-ritual kematian untuk membantu dalam perjalanan menuju kebahagiaan abadi. Dengan kata lain hal ini mau menyampaikan suatu pesan bahwa kematian adalah budaya Jawa tidak di pandang sebagai hal yang sia-sia namun menjadi jalan bagi manusia untuk mencapai kesempurnaan.

Konsekuensi dari adanya paham hidup abadi adalah perlakuan orang terhadap jenasah. Tubuh orang yang telah meninggal akan mendapatkan perawatan sebelum di kebumikan. Setiap ritual perawatan dari memandikan hingga masuk ke liang lahat memiliki banyak aturan dan simbol-simbol tertentu. Tujuan utama dari perawan itu tidak lain adalah menghormati orang yang telah meninggal dan mempersiapkan untuk perjalanan gaibnya (alam setelah kematian).

Pandangan yang menyatakan manusia tetap hidup meskipun telah mengalami kematian badani juga mempengaruhi sudut pandang masyarakat berkaitan dengan struktur sosial.

Ini merupakan runtutan ritual-ritual atau upacara adat Hindu Jawa yang sampai saat ini masih melekat yaitu sebagai berikut :

\section{Hari Kematian}

Hari kematian menurut budaya Jawa, merupakan hari atau saat keluarnya roh dari 
jasad seseorang. Orang jawa lebih sering menyebutnya dengan hari na-as/geblag/sedone seseorang, hari kematian ini (dino pasaran) dipergunakan sebagai pedoman awal untuk acara prosesi selamatan maupun upacara adat berikutnya.

Hari na-as (jumlah dino pasaran) ini merupakan gambaran masa depan anak cucu atau keturunannya atau keluarganya misalkan dengan menghitung neptu dino pasaran pada saat meninggal dijumlahkan kemudian dihitung masuk dalam kategori: gunung, Guntur, segoro, atau asat. Jika jatuh pada gunung maka rejeki keluarga dan anak keturunannya berlimpah seperti gunung. Jika jatuh pada Guntur makan rejeki keluarga yang di tinggalkan akan mengalami penurunan atau kekeringan. Jika jatuh pada segara maka rejeki keluarga yang di tinggalkan akan selalu bersumber dan tidak akan ada habis-habisnya seperti air samudera. Jika jatuh pada asat maka gambaran rejeki keluarga yang di tinggalakan akan serba paspasan bahkan mengarah ke kekurangan termasuk untuk doa selamatan pun selalu serba kekurangan.

\section{Brobosan}

Yakni suatu upacara atau ritual yang dilakukan di halaman rumah orang yang meninggal. Waktu dilaksanakan ketika jenazah akan di berangkatkan ke peristirahatan terakhir (dimakamkan) dan di pimpin oleh salah satu anggota keluarga yang paling tua. Tata cara pelaksanaanya antara lain : 1) Keranda/peti mati di bawa keluar menuju halaman rumah dan di junjung tingga ke atas setelah doa jenasah selesai; 2) secara berturut-turut ahli waris yang di tinggal (mulai darianak laki-laki tertua hingga cucu perempuan) berjalan melewati keranda yang ada di atasnya (mbrobos) sebanyak tiga kali dan seraah jarum jam. Upacara ini bertujuan untuk menghormati, menjunjung tinggi, dan mengenang jasa-jasa almarhum semasa hidupnya dan memendam hal-hal yang kurang baik dari almathum. Dalam istilah Jawa nya adalah "mikul dhuwur mendhem jero".

\section{Prosesi Selamatan Hari Kematian.}

Prosesi selamatan orang meninggal dalam budaya Jawa dilakukan beberapa kali terhitung semenjak orang tersebut meninggal. Menurut pujangga untuk mempermudah kita mengingat prosesi tersebut menciptakan sebuah tembang Mocopat Sinom yaitu sebagai berikut:

"Siji-siji yen nyurtanah, telu-telu telung ari, pitu loro pitung dino, limo-limo kawandesi, loro limo nyatusi, papat-papat mendhakipun, kanem klawan kalimo wilujenge sewu ari, den prastitis dino taun sasi tanggal"

\section{Artinya:}

Satu-satu untuk nyurtanah, tiga-tiga untuk tiga hari, tujuh dua untuk tujuh hari, lima-lima untuk empat puluh hari, dua lima untuk seratus hari, empatempat untuk satun tahun, enam lima untuk seribu hari, perhatikan secara teliti hari, tahun, bulan dan tanggal.

Tujuan singkatnya adalah untuk mengantarkan langkah orang yang sudah mati tersebut dalam perjalanan menuju kesempurnaan baik jiwa maupun raganya. Berikut runtutan prosesi upacara kematian adat Jawa:

a. Ngesur/Njur tanah. Acara prosesi yang dilakukan biasanya setelah jenasah di berangkatkan ke pemakan, di siapkan banten tumpeng ungku-ungkur yang artinya adalah keluarga berharap yang meninggal dengan ihklas meninggalkan alam dunia ini dan menuju alam akhirat dengan penuh keihklasan dan dimudahkan jalannya menuju tempat kuburnya dalam bahasa Jawa dengan menyebut jembar dalane, ombo kubure. Sedangkan yang di tinggalkan semoga dapat melupakan yang meninggal dan mengilangkan rasa berkabungnya, selanjutnya segera dapat mengurus keluarga yang di tinggalkan/yang masih hidup di dunia. Jadi prosesi hari pertama atau pas hari meninggalnya, sinep jiwa ini yaitu tujuan dari pada upacara atau ritual tersebut adalah untuk proses pengembalikan sang jiwa kepada sang pencipta. (Wawancara, Pandhita Rsi Agung Hasto Darma Eka Telabah, Sidoarjo, Januari 2019). 


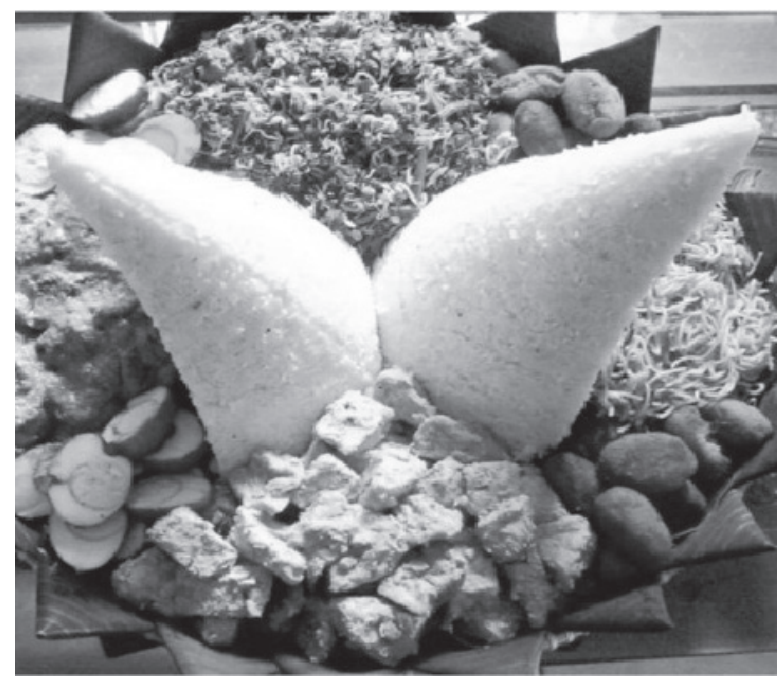

Gambar Tumpeng Ungkur-ungkur

b. Prosesi Selamatan pada hari kedua, yaitu pada hari ini mohon restu kepada para leluhur, proses Manunggal Kawulo Lawan Gusti. (Wawancara, Pandhita Rsi Agung Hasto Darma Eka Telabah, Sidoarjo, Januari 2019).

c. Prosesi Selamatan pada hari ketiga atau nelung dino cara menentukan hari pasaran selamatan ini yaitu dengan cara menentukan hari dan pasaran nelung dino digunakan rumus nolusarlu, yaitu hari ketiga dan pasaran ketiga. Tujuan dari acara selamatan telung dino ini adalah untuk menyempurnakan nafsu yang ada dalam jasad manusia yang berasal dari bumi, api, air dan angin. Kondisi jasad/mayat mulai membekak (ngabuh-ngabuhi). Dan Arwah/roh masih berada di sekitar rumah (ngubeng omah).Dan prosesi telung dino ini sebagai permohon kepada Dewa Brahma, Dewa Wisnu dan Dewa Shiwa (Tri Murti) (Wawancara, Pandhita Rsi Agung Hasto Darma Eka Telabah, Sidoarjo, Januari 2019).

d. Prosesi selamatan pada hari keempat, yaitu bertujuan melepas unsur-unsur dalam badan. (Wawancara, Pandhita Rsi Agung Hasto Darma Eka Telabah, Sidoarjo, Januari 2019)

e. Prosesi Selamatan pada hari kelima, yaitu sebagai proses penyempurnaan diri, sodara empat lima pancer. Nuntun jiwa untuk mencapai kesempurnaan (Moksa). (Wawancara, Pandhita Rsi
Agung Hasto Darma Eka Telabah, Sidoarjo, Januari 2019).

f. Prosesi selamatan pada hari keenam, yaitu prosesi nuntut sang jiwa, supaya tidak bingung, jadi tau arah untuk menuju alam niskala. (Wawancara, Pandhita Rsi Agung Hasto Darma Eka Telabah, Sidoarjo, Januari 2019).

g. Prosesi selamatan pada hari ketujuh mitung dino ini yaitu proses penyempurnaan tujuh lapisan dalam tubuh yaitu (wulu, daging, otot, getih, kulit, balung, sumsum). (Wawancara, Pandhita Rsi Agung Hasto Darma Eka Telabah, Sidoarjo, Januari 2019). Cara menentukan waktu selamatan Mitung Dino ini yaitu hari dan pasaran mitung dino digunakan rumus notusaru yaitu hari ke tujuh dan pasaran ke dua. Kondisi jasad/mayat mulai meletus atau mengeluarkan gas dari dalam tubuh (mbledos), dan kondisi arwah/roh masih berada di sekitaran rumah (ngubeng omah).

h. Prosesi selamatan pada hari ke empat puluh metang puluhi, yaitu selamatan setelah empat puluh hari kematian. selamatan ini bertujuan untuk penyempurnaan anggota tubuh yang merupakan titipan dari kedua orang tua, yaitu, darah, daging, sumsum, tulang dan otot pada hari ini semua unsur itu sudah mulai mengering. Cara menentukan waktu selamatan hari dan pasaran matang pupuh dino di gunakan rumus nomasarma yaitu hari kelima pasaran kelima. Kondisi jasad/mayat mulai proses pembusukan (mbosoki). Dan kondisi arwah mulai menjauh dari rumah namun kadang-kadang masih kembali ke rumah (ngedohi omah).

i. Prosesi selamatan setelah saratus hari kematian yaitu nyatus dino tujuan dari pada selamatan ini adalah untuk penyempurnaan badan/jasad, sang jiwa, dan sang atman sudah mulai lepas atau terputus dengan keluarga, unsur-unsur tubuh juga sudah mulai lepas atau mulai mengering (ngesat-ngesati). (Wawancara, Pandhita Rsi Agung Hasto Darma Eka Telabah, Sidoarjo, Januari 2019) Penyucian ruas tulang-tulang yang kecil- 
kecil. (wawancara, Dewo Suratnaya, Januari, 2, 2019).

j. Prosesi selamatan setelah satu tahun kematian yaitu Pendak sepisan, tujuan dari pada selamatan ini adalah untuk proses penyatuan, atau telah sempurnanya kulit, daging dan isi perut. Kondisi jasad daging sudah habis tinggal tulang belulang. Dan roh sudah mulai menjauh dari keluarga. Dan untuk menentukan waktu selamatan hari dan pasaran mendhak sepisan di gunakan rumus nopatsarpat yaitu hari keempat dan pasaran keempat.

k. Prosesi selamatan setelah dua tahun kematian yaitu Pendak Pindo, tujuan dari pada selamatan ini adalah sempurnanya semua anggota badan selain tulang belulangnya. Kondisi jasad tulang belulang sudah mulai lepas dari persendiannya (balung gonggang) dan kondisi roh sudah mulai menjauh dari rumah.

I. Prosesi selamatan setelah seribu hari kematian yairu nyewu, cara menentukan waktu selamatan hari dan pasaran nyewu adalah di gunakan rumus nonemsarma yaitu hari keenam dan pasaran kelima. Tujuan dari pada selamatan ini adalah karena telah sempurnanya jasad manusia termasuk bau dan rasanya. Sehingga manusia yang meninngal itu sudah menyatu dengan tanah yang merupakan asal muasalnya. Dan untuk mengembalikan karma, secara niskala yaitu keluarga yang di tinggalkan supaya tidak mengalami, secara skala yaitu di jalankan sesuai karma. Dan selamat ini merupakan Penghormatan terakir kepada leluhur. Kondisi jasad tinggal tulang belulang dan kondisi roh sudah menempati alam yang semestinya sesuai dengan karma yang dilakukan semasa hidup di dunia.

m. Pangentas, prosesi upacara ini yaitu prosesi untuk penyempurnaan karma untuk bisa mencapai Moksa atau lahir kembali. Dan upacara ini dilakukan setelah upacara seribu hari. Sebagaimana tecantum di dalam pustaka Iswara Tattwa, sebagai berikut :

“Ceritakan sekarang Bhagawan
Dharmaraja diberikan anugerah oleh Sang Nabhe melaksanakan rangkaian upacara mengentaskan orang meninggal, turut dalam "barisan" Tri Sadhaka Wisesa, sama-sama memberikan tirtha penglepas kepada orang meninggal di jagat Purbha Sasana. Tidak ada yang membencanai negerinya itu, malah bertambah-tambah kesejahteraan dan ditakuti musuh. Sri Jaya Wikrama, dan seluruh atma orang yang dientaskan oleh Sang Tri Sadhaka wangsa, berubah menjadi watek Gandharwa. Segala dosa papa-pataka ketika masih ada di alam manusia sirna oleh mantra Sang Tri Shakti. Itulah sebabnya jagatnya menjadi selamat, tidak ada orang mati semasih bayi. Tidak ada penyakit, segala yang di tanam tumbuh, murah segala yang di jual, sedikitlah penderitaan di dunia, karena bhuwana sudah rahayu. Huruhara tidak ada, usia orang sesuai dengan jatah hidupnya, tercapailah janji hidupnya. Sang Brahmana dan satriya ber-iringan, dipastu oleh Bharata Shiwa mebuat hidup di dunia jagat, membuat jalan yang benar sampai pada kematiannya. Karena Sang Tiga itu adalah perwujudan dari Shiwa, Sadashiwa, Paramashiwa. Sang Wiku Tiga Wisesa mengasuh dunia siang dan malam, hidup mati, seluruh jagat, sampai Shiwa Budha Satriya putus itu pulalah yang memberikan pengelepasan pada Atman. $\mathrm{Tu}$ semua karena anugerah Bhatara Shiwa. Agar mencapai sorga atma orang yang meninggal. Seperti itulah anugerahku kepada dirimu, muridku. Jangan sampai tidak mempercayai ucapan diriku ini. Begitu pula seluruh yang ada di bawah langit ini, Satriya juga mengentaskan atma. Apabila Brahmana, raja sampai mati. Pendeta brahmana boleh mengentaskan Shiwa Budha. Kalau Bujangga Ratu Putus, seluruh Wangsa satriya boleh di entaskan sampai pada wesya wangsa sudra, seriringan dengan Buddha Shiwa. Kalau yang meninggal berwangsa brahmana, tidak boleh pendeta satriya memberikan tirtha penglepas atma. Ini patut ditiru, karena menyebabkan kebaikan di dunia". (IT) 
(IBM Dharma Palguna, 2018, 23-24).

Manfaat dan tujuan dari pada upacara entasentas yaitu sebagai berikut : 1) Leluhur yang sudah dientas diseberangkan menuju kesempurnaan menjadi Istadewata, sehingga kalau reinkarnasi akan mendapatkan badan yang baik, organ tubuh yang sempurna dan kehidupan yang bahagia. Tidak ada lagi anak cucu yang menderita penyakit karma, seperti jantung bocor, ayan, kepala membesar dll.; 2). Leluhuryang dientas tidak akan lagi gentayangan dan tidak lagi menimbulkan kesurupan ramerame di mana-mana; 3) Leluhur yang sudah dientas dan statusnya sudah Istadewata akan mengingatkan keturunannya untuk kembali ke jalan dharma; 4) Dengan dientasnya para leluhur, maka limbah-limbah di permukaan bumi akan jauh berkurang, sehingga pikiranpikiran jernih akan bermunculan di bumi; 5) Para leluhur yang dientas akan ikut serta dalam menentukan perjalanan sebuah bangsa; 6) Lebih jauh leluhur yang sudah disempurnakan akan ikut serta dalam mengembalikan kemuliaan Nusantara; 7) Leluhur yang sudah dientas akan melindungi, mengayomi dan memberikan kemakmuran dan kesejahteraan bagi keturunannya. Dalam prosesi upacara entas-entas ini Sarana-sarana yg dibutuhkan adalah sebagai berikut: 1) Cengkir kelapa bulan tiga buah, kelapa udang tiga buah, kelapa gading sebelas buah, kelapa ijo tiga buah dan kelapa sudamala tiga buah; 2) Kain putih tujuh meter; 3) Daksina linggih tiga set (lanang istri) dan sangge; 4) Daun bunga teratai tiga lembar; 5) Daksina pejati lima set; 6) Byakala satu set, durmanggala satu set, prayascitta satu set; 7) Segehan manca warna lima tanding; 8) Canang sepuluh buah; 9) Sandingan cok bakal komplit empat set ( isinya beras satu kg dan satu genggam, daun jati sembilan lembar), pisang raja enam sisir, kelapa tua enam butir (tidak dikupas), cok bakal lengkap tiga buah; 10) Cok bakal lengkap empat buah; 11) Crucut bakal empat buah; 12) Tumpeng satu set lengkap dengan panggang ayam, urab-urab, lauknya : ikan laut, tahu, tempe; 13) Sego golong (nasi berbentuk bulat) sebelas buah; 14) Nasi kuning satu buah ancak; 15) Apem goreng empat puluh empat buah; 16) Sego karak satu piring; 17) Jajan pasar tujuh jenis; 18) Bubur merah putih masing-masing dua takir; 19) Bubur tulak bala (hitam-putih) satu1 takir; 20)Bubur tulak sengkolo (kuning-hijau-merah) satu takir; 21) Beras kuning satu kilo gram dan uang logam lima ratus rupiah sebanyak tiga koin utuk setiap jiwa yang didaftarkan untuk di entas, yang dicampur dengan beragam bunga; 22) Sebatang daun pisang muda (pelosor) yang masih tergulung; 23) Tanaman penuntun (disesuaikan dengan tempat prosesi entas-entas). (wawancara, Dewo Suratnaya, Januari, 2. 2019).

\subsection{Relevansi Pelaksanaan Upacara Pitungdino Kematian Masyarakat Hindu Di Jawa Dengan Umat Hindu Di Bali.}

Dalam proses pemeliharaan Jenazah atau suatu upacara sesuai dengan tempat mendem. Tradisi Pitra Yajna berbeda-beda untuk masingmasing etnis/daerah sesuai dengan Desa Kala Patra masing-masing. Di bali tidak ada prosesi upacara tujuh hari (pitungdino kematian) namun upacara untuk tiga hari (telung dino) itu sangat umum dan tidak hanya berlaku untuk Pitra Yajna saja melainkan untuk semua Panca Maha Yajna. Upacara empat puluh hari dan upacara Seribu Hari juga tidak ada di Bali namun untuk upacara Manusa Yadnya ada upacara 42 hari dan 105 hari. Demikian pula upacara seribu hari tidak di kenal di Bali namun yang ada adalah upacara Pengabenan/Pelebon. (wawancara, Nengah Dana, Januari 2019).

Dari uraian di atas korelasi dari pitungdino kematian dengan upacara kematian di bali sama-sama mengusung konsep memuja leluhur/ngelinggihan leluhur. Dan juga samasama mempunyai tujuan konsep mendewatakan leluhur (wawancara, Dewo Suratnaya, Januari, 2 2019). Sebagai simbul stana leluhur jika di bali terdapat pelinggih Kemulan rong telu yaitu tempat kelinggihan para leluhur yang sudah meninggal. Merupakan pelinggih yang. paling inti dalam sanggah atau Merajan. Dalam Pelinggih Kemulan Rong Telu sesungguhnya yang disembah atau diungsung adalah Ida Bhatara Guru atau leluhur yang telah di suci. Sedangkan di adat Hindu Jawa terdapat Sentong Tengah kurang lebih fungsinya hampir sama dengan Rong telu. Sentong Tengah mempunyai nilai yang paling sakral dibandingkan dengan senthong kiwo maupun senthong tengen, karena senthong tengah biasanya di khususkan untuk ruang sembahyang. Ruang senthong tengah 
adalah tempat untuk menghadirkan dewa-dewi, bethara-bethari, maupun para leluhur.

Ruang senthong tengah disebut juga dengan berbagai nama, seperti kerobongan, pasren dan pedaringan. Kerobongan berarti tempat pembakaran (berasal dari kata obong yang berarti bakar). Di sebut demikian karena senthong tengah merupakan tempat untuk membakar kemenyan ketika si pemilik rumah melakukan upacara pitra yadnya (pemujaan kepada leluhhur). Pasren berasala dari kata pasri-an, yang berarti tempatnya Dewi Sri, dewi penguasa tanaman padi. Sedangkan pendaringan berarti tempat padi.

Di dalam ruang senthong tengah biasanya terdapatprasaranaupacarauntukmenghadirkan dewa-dewi, bhetara-bhetari atau leluhur yang akan di puja. Kelengkapan prasana sembahyang tersebut ditentukan oleh kemampuan pemilik rumah. Prasana kelengkapan yang paling sederhana adalah meja sesaji yang pada umumnya di miliki oleh masyarakat petani. Meja sesaji ini fungsinya adalah untuk meletakkan sesaji ketika pemilik rumah sembahyang, melakukan upacara slametan/kenduri, atau sesaji pas geblaknya sodara yang meninggal, maupun untuk meditasi. Meja sesaji ini juga di gunakan untuk menghaturkan sesaji pada saat hari raya Galungan, Kuningan, purnama -tilem, saraswati, Siwaratri dan Nyepi.

Sebagaimana telah di sebutkan di atas, bagi masyarakat Jawa yang termasuk dalam golongan priyayi dan bangsawan, di samping meja sesaji, di dalam ruangan senthong tengah juga terdapat prasarana berupa tempat tidur berukuran kecil, tetapi lengkap dengan dengan kasur, bantal, guling dan sprei, karena berukuran kecil, tempat tidur itu tidak mugkin ditempati oleh manusia. Tempat tidur tersebut merupakan "pelinggih" bagi dewa-dewi, bhetara-bhetari, atau leluhur. Pada golongan bangsawan tingkat tinggi, di depan tempat tidur ditambahkan dengan sepasang arca pengantin dari tanah liat yang di sebut dengan loroblonyo. Loroblonyo merupakan lambang daulis dalam kehidupan yang bila bersatu menimbulan suatu keharmonisan. Dalam agama Hindu konsep dualis ini disebut dengan Rwa Bhineda.

\subsection{Melaksanakan Upacara Pitungdino Kematian.}

Bagi keluarga yang di tinggalkan, tujuan dari pada upacara Pitra Yajna yaitu upacara Pitungdino Kematian ini di laksanakan yaitu bertujuan untuk pengabdian dan rasa bhakti kita yang sangat tulus ikhlas kepada para leluhur kita, mengangkat serta menyempurnakan kedudukan arwah para leluhur kita di alam Swah Loka, dan memperhatikan kepentingan orang tua dalam mewujudkan rasa bhakti. Hal tersebut di laksanakan atas kesadaran bahwa sebagai keturunanya ia telah berhutang kepada Orang tua/leluhur seperti, berhutang badan (Sarira Khosa) atau disebut dengan istilah Sarirakrit, berhutang budi (Anadatha), berhutang jiwa (Pranadatha). Dalam kita melaksanakan upacara Pitra Yajna salah satunya Upacara Pitungdino Kematian di dasari atas hukum sebab akibat juga yaitu dari Karma Phala, sebagai keyakinan adanya Punarbhawa dan kita percaya bahwa leluhur itu masih hidup di dunia (alam semesta) ini.

Pandangan dalam agama Hindu tentang kehidupan yang ideal duniawi dibentuk oleh konsep etika tentang konsep tiga hutang bahwa seseorang itu harus membayar selama kehidupan sesorang. Tiga hutang ini berhubungan dengan tiga hutang dlam kehidupan seseorang. Hutang ini bukanlah harfiah, dalam pengertian pertanggung jawaban yang lahir bersama dan menghabiskan kehidupannya mencoba untuk membayarnya. Sebaliknya,konseptigahutanginimencerminkan usaha lain sebagai bagian dari pemikiran Hindu untuk menciptakan kesadaran dari tugas dan tanggung jawab seseorang.

Setiap anak mempunyai kewajiban mendoakan orang tuanya, karena ini merupakan bentuk rasa bhakti seorang anak kepada orang tua. Kita sangat penyadari akan hal ini karena dalam ajaran agama Hindu mengajarkan tentang ini yaitu ajaran tentang Tri Rna yaitu tiga hutang yang harus kita bayar atau kita laksanakan dalam hidup ini, tiga hutang itu yaitu pertama Dewa Rna yaitu hutang kepada Shang Hyang Widhi Wasa yaitu hutang berupa jiwa atau kehidupan, kita sangat menyadari bahwa dari Tuhanlah kita hidup. Hutang pertama inilah kita hars membayar dengan mempersembahkan kehidupan seseorang untuk melayani Tuhan. Bagi seorang Hindu, pelayanan pada Tuhan 
berarti pelayanan bagi semua manusia, tidak memandang kasta, warna dan keturunan. Penghormatan kepada semua bentuk kehidupan, termasuk tanaman dan binatang, dan perlindungan pada lingkungan adalah bagian penting hutang pertama ini. Pelayanan kepada Tuhan juga termasuk menerapkan anti kekerasan dan kebenaran, mematuhi aturan kitab suci Hindu, berlatih untuk mengendalikan diri dan kemurnian pikiran, terutama pada orang yang lebih tua. Dalam budaya Hindu, menghargai dan menghormati semua orang yang lebih tua sebagai bagian dari pembayaran hutang kepada Tuhan. Dalam kitan Taittiriya Upanisad 1.11 menyatakan bahwa orang tua dan guru harus diperlakukan sebagai Dewa.

Kedua Pitra Rna yaitu hutang kepada orang tua atau leluhur hutang ini merupakan hutang kelanjutan hidup, hutang budhi, hutang badan, karena kita pun menyadari bahwa untuk kehidupan lahir bhatin, kita telah menerima dan mewarisinya dari orang tua dan dari para leluhur. Hutang ini dapat di bayar dengan menjaga dan memperkaya warisan budaya yang di wariskan melalui setiap generasi untuk menjaga dan memperkaya warisan budaya, seseorang harus belajar dan menerapkan filsafat dan theology Hindu Dharma. Untuk mencapai tujuan ini, seseorang harus melakukan pelayanan kepada masyarakat. Aktifitas ini membantu untuk menguraikan ajaran kitab dan menggambarkan bagimana kebijaksanaan spiritual pada Rsi dan orang suci Hindu dapat digunakan untuk memecahkan permasalahan untuk menghadapi dunia saat ini.

Yang ketiga yaitu Rsi Rna yaitu hutang kepada seorang guru pengajian berupa berbagai ilmu pengetahuan, sehingga kita mengenal tentang arti hidup dan tahu akan tujuan hidup yang sebenarnya.

Dalam melaksanakan Tri Rna ini kita tidak pernah bisa lepas dari yang namanya Panca Yadnya karean dari Tri Rna inilah yang menimbulan Panca Yadnya

Dalam Kitab Manawa Dharmasastra VI.35 menyatakan sebagai berikut:

Rinani trinyapakritya manomokse
niwecayet
$\begin{aligned} & \text { Anapakritya moksam tu sewamano } \\ & \text { wrajatyadhah. }\end{aligned}$

\section{Artinya:}

Kalau ia telah membayar tiga macam hutangnya (kepada Tuhan, kepada leluhur dan kepada orang tua), hendaknya ia menunjukka pikirannya untuk mencapai kebebasanan terakhir, ia yang mengejar kebebasan terakhir ini tanpa batas menyelesaikan tiga macam hutang akan tenggelam ke bawah.

Jadi menurut pernyataan dari sloka di atas bahwa hendaknya pikiran jangan di arahkan pada tujuan akhir mencapai kebebasan (Moksa) sebelum sebelum melunasi tiga macam hutang moral. Tiga macam hutang moral itu adalah Tri Rna yaitu hutang kepada Tuhan, kepada leluhur dan kepada para Rsi. Kalau mencari kebebasan terakhir tanpa menyelesaikan tiga hutang tersebut justruakan membawa orang terjerumus ke bawah. Untuk menyelesaikan tiga hutang tersebut umat Hindu melakukan lima macam Yajna yang di sebut dengan Panca Yajna. Dalam ajaran kitab Manawa Dharma Sastra inilah nampaknya yang sangat di pahami oleh umat Hindu sehingga dalam hidupnya terus berupaya untuk melaksanakan Panca Yajna sebagai upaya untuk menyelesaikan tiga hutang moral tersebut. Salah satu tiga hutang tersebut adalah Pitra Rna yaitu hutang kepada orang tua atau para leluhur.

Hutang kepada para Pitra di selesaikan dengan cara melakukan Pitra Yajna dan Manusa Yajna. Mengapa Manusa Yadnya menjadi media menyelesaikan Pitra Rna, yaitu salah satunya dasar keyakinan Hindu adalah percaya pada Punarbhawa (reinkarnasi). Anak-anak itu tidak lain adalah leluhurnya yang kembali menjelma untuk memperbaiki karmanya. Hidup di dunia ini adalah kesempatakan untuk memperbaiki karma supaya terus meningkat sampai mencapai Moksa. Dengan melakukan Yajna pada anakanak berarti beryajna kepada leluhur juga. Ini lingkaran moral yang sangat indah yang di ajarkan dalam ajaran agama Hindu.

Dalam kitab Bhagawad Gita IX.25 menjelaskan sebagai berikut :

Yanti deva vrata devan, pitrn yanti pitr vratah

Bhutani yanti bhutejya, yanti mad yajino pi mam 


\section{Artinya:}

Yang memuja dewata pergi kepada para Dewata, kepada leluhur perginya yang memuja leluhur mereka, dan kepada roh alam perginya yang memuja roh alam, tetapi mereka yang memuja-Ku datang pada-Ku. (Bhagawadgita, Pudja 2005:25)

Dalam sloka Bhagawad Gita tersebut menandakan dalm system penyembahan Hindu dikenal adanya penyembahan berjenjang. dari menyembah Bhuta, Dewa dan Pitara (leluhur). Kata sembah berasal dari bahasa Jawa Kuna yang memiliki lima arti yaitu menghormati, menyayangi, memohon, menyatukan diri dan menyerahkan diri secara total.

Demikianlah Tri Rna dimiliki manusia sebagai umat Hindu yang wajib dibayar melalui pengalaman Panca Yadnya dalam kehidupan ini. Secara duniawi sesungguhnya setiap orang beragama mengakui adanya tiga hutang seperti itu walaupun tidak disebutkan secara jelas dalam ajaran agama. Panca Yadnya ialah lima jenis korban suci yang dilaksanakan oleh umat Hindu untuk mencapai kesempurnaan hidup. Orang yang tidak mengamalkan Panca Yadnya akan menjadi semakin banyak hutang yang dia pikul dan mereka akan menjadi semakin serakah serta sombong. Hal itu menyebabkab orang semakin pasti masuk neraka akhirat. Disamping Panca Yadnya untuk membalas jasa kepada Dewa, Rsi dan Pitra/Leluhur, maka yadnya dapat mengantarkan pelakunya menuju alam sorga dan moksa. Seperti di sebutkan dalam kitab Manawa Dharma Sastra sebagai berikut :

Dewatathiti bhrtyanam, pitri rnam atman as ca yah,

Na nirwapati pancanam, ucchwsanna sa jiwati (III.72)

\section{Artinya:}

Tetapi mereka yang tidak melaksanakan persembahan Panca Yadnya yaitu kepada Tuhan (Dewa-Dewa) orang suci, makhluh bawahan, para leluhur dan sesamanya pada hakekatnya mereka adalah mati walaupun bernafas. (III.72)

Wedabhyaso nwaham saktya, mahayadnya kriya ksama,

Nasa yantyasu papain, maha pataka janiapi.(XI.246)

\section{Artinya:}

Dengan memahami Weda, melaksanakan maha Yadnya (Panca Yadnya) menurut kemampuan, dan sabar terhadap penderitaan, cepat atau lambat akan menghilangkan semua noda walaupun sampai dosa besar (XI.246).

Demikianlah yadnya yang patut dilaksanakan oleh umat Hindu dengan berpedoman Desa, Kala, Patra/Tattwa/Sastra. Desa adalah tempat dimana yadnya itu dilaksanakan; Kala adalah waktu (saat kapan yadnya itu dilakukan); Patra adalah sastra/ajaran agama/petunjuk yang benar. Jika di bandingkan Tri Rna dengan Panca Yadnya maka 1). Dewa Rna dibayar dengan Dewa Yadnya dan Bhuta Yadnya. 2). Pitra Yadnya dibayar dengan Pitra Yadnya dan Manusia Yadnya. 3). Rsi Rna dibayar dengan Rsi Yadnya. Dengan memperhatikan bentuk-bentuk pelaksanaan yadnya dalam Panca Yadnya, jelaslah bahwa itu bukan hanya upacara ritual.

\subsection{Manfaat Upacara pitungdino Kematian}

Manfaat yang didapat dari rangkaian upacara tersebut untuk anak, cucu dan keturunanya yaitu untuk kesejahteraan, dan perubahan alam sekitar secara skala dan niskala. Dalam Kakawin Niti Sastra menjelaskan sebagai berikut:

Mwang dinatithi yogya sunggana dana tekapira sang uttameng praja

Mwang dewa sthana tan winursita rubuh wangunen ika paharja sembahen,

Dina preta sangaskara ta pahayun lepasakena teken smasana ya,

Byakta labhaning aswamedha kretu labhanira siniwi ring suralaya.

\section{Artinya:}

Orang terkemuka yang di muliakan rakyatnya patut memberikan sedekah kepada tamu yang miskin, dan membangun kembali candi yang sudah roboh dan tidak terpakai lagi, lalu menghiasinya supaya dapat dipergunakan lagi sebagai tempat bersembahyang. Ia patut mengadakan korban bagi jiwa-jiwa yang sengsara, supaya jiwa-jiwa itu terlepas dari kubur. Dengan jalan begitu ia berjasa seperti orang yang mengadakan korban Aswamedha yang mampu mengantarkan 
jiwanya menuju Swargaloka. (Kakawin Niti Sastra IV.6).

Orang-orang yang terkemuka misalnya seorang raja, memiliki kewajiban untuk memberikan dana punya kepada masyarakat yang membutuhkan, menghormati tamu yang datang, dan membangun tempat-tempat suci untuk menyembah para Dewa dan para leluhur. Dengan memberikan dana punya kepada orangorang miskin maka harta kekayaannya akan tersucikan. Penghormatan kepada tamu (athiti puja) yang ia lakukan akan melancarkan rezekinya. Dan dengan membangun Pura, kuil atau tempat suci ia telah membuka jalan menuju swarga loka. Juga di sebutkan dalam Parasara Dharmasastra I.39 sebagai berikut:

Sandhya snanam japo homah swadhyayo dewatarcanam.

Waiswadewatitheyan ca sat karmani dine dine.

\section{Artinya:}

Melaksanakan penyucian pada pertemuan waktu (sandhya), japa homa, mempelajari Weda, pemujaan kepada arca para Dewa, kurban suci untuk para Dewa, dan menghormati tamu yang datang merupakan enam kewajiban yang diperintahkan dalam Weda. (Kakawin Niti Sastra, miswanto:2015:197)

Selain memiliki kewajiban untuk bersedekah, menghormati tamu, mebangun tempat-tempat suci, pemujaan kepada para Dewa dan penghormtan kepada para leluhur, umat Hindu yang merasa mampu memiliki kewajiban untuk mengadakan Aswamedha Yajna untuk membebaskan atman para leluhur mereka. Dalam cerita Itihasa Ramayana, hal ini pernah dilaksanakan oleh Raja Sagara dari Kosala (Ayodhya) dengan mengorbankan puluhan ribu kuda, dan dengan upacara itu, makaseluruh arwah leluhurnya bisa diangkat menuju Swarga loka. Upacara yang sejenis ini juga pernah dilakukan oleh Raja hayam wuruk terhadap Sri Rajapatni (ratu Gayatri) pada bulan Badrapada tahun Saka 1284 (sekitar bulan Agustus 1362 M). hal ini sebagaimana terugkap dalam kakawin Negarakrtagama LXIII.2 sebagai berikut:

Ajna sri natha sang sri tribhuwana wijayottungadewi
Sradda sri rajapatni wkasana gawayen sri narendreng kadatwan

Siddaning karyya ring saka diwasa masirah warna ring bhadramasa

Sakweh sri natha rakwawwata tadah irirnen de.

\section{Artinya:}

Atas perintah Ratu Sri Tribhuwana Wijayatunggadewi, supaya pesta Sraddha Sri Rajaptni atau Ratu Gayatri dilangsungkan Sri Baginda Maharaja (Hayam Wuruk) di istana pada tahun Saka bersirah empat (1284) bulan Badrapada. Semua pembesar dan Wredda menteri di harapkan ikut berpartisipasi dengan memberi sumbangan.

Senada dengan hal tersebut, dalam kitabkitab Upanisad jiwa sering kali digambarkan sebagai seberkas cahaya yang bersemayang dalam sebuah goa yang rasasia di dalam hati. Dari snalah jiwa seperti mercusuar yang membimbing para nelayan untuk mencapai tujuannya. Selain itu jiwa juga dikenal sebagai antaryamin yang menyaksikan seluruh perbuatan manussia. Tetapi karena jiwa diikat oleh tiga mala yaitu anawa atau ketidak murnian, karma atau perbuatan dan maya atau ilusi. Maka jiwa-jiwa itupun bisa menderita dan sulit bebas dari kubur jika selama hidupnya ia banyak melakukan perbuatan-perbuatan yang tidak suci, karma buruk, dan masih terbelenggu oleh maya.

Kramaning dadi wwang ana ring bhuwana pahutanganta ring praja.

Ri sirang munindra nguniweh sang atithi gamaneka sambaraman.

Athawa muwah swa-pita rahyang amara rena yogya kingkingen.

Panahurta ring pitara potraka luputakening yamalaya.

\section{Artinya:}

Manusia di atas dunia ini mempunyai kewajiban terhadap sesamanya. Orang yang suci, apalagi tamu, wajib diperlalukan dengan hormat. Terlebihlebih kewajiban kita terhadap orang tua, orang-orang suci dan Dewa-Dewa, harus selalu diingat. Sebagai anak kita berkewajiban melepaskan nenek- 
moyang kita dari kediaman Betara Yama. (Kakawin Niti Sastra IX.2)

Setiap manusia memiliki kewajjiban untuk menghormati para Dewa, leluhur, orang tua, orang-orang suci dan tamu yang datang ke rumahnya. Hal ini merupakan perintah Weda kepada seluruh umat manusia. Kita berhutang kepada para Dewa sebagai manifestasi Brahma yang telah menciptakan dana memelihara alam semesta. Kita juga berhutang kepada para leluhur dan orang tua yang telah menjadikan kita lahir di dunia. Kita berhutang kepada orangorang suci yang telah memberikan pengetahuan suci kepada umat manusia di dunia. Kita juga berhutang kepada tamu yang hadir dengan segala keberuntungan yang dibawanya.

Senada dengan hal tersebut, pada bab Siksa Walli atau Samhita dalam Taittiriya Upanisad I. XI.2 sebagai berikut:

Dewa pitr karyabhayam na pramadi
tawyam, matr dewo bhawa,
pitr dewo bhawa, acarya dewo bhawa,
atithi dewo bhawa.

\section{Artinya:}

Janganlah pernah ingkar terhadap kegiatan pemujaan kepada para Dewa dan para leluhur. Sebagaimana dikatakan dalam Weda bahwa; Ibu adalah perwujudan Dewa; Ayah adalah perwujudan Dewa; Guru adalah perwujudan Dewa; Tamu adalah perwujudan Dewa. (Kakawin Niti Sastra IX.2).

Dari sloka di atas dapat diketahui bahwa selain kita tidak boleh mengingkari Tuhan beserta manifestasi-Nya, kita juga harus bisa menghormati orang tua dan tamu yang datang kepada kita. Di samping menghormati semua orang adalah kebaikan yang harus selalu dibiasakan. Dengan selalu menghormati dan menghargai sesama manusia maka kita menuai buah kebajikan untuk kita sendiri. Kita juga tidak boleh membeda-bedakan sesorang yang layak untuk kita hormati, misanya seperti orang yang berduit saja, orang yang punya kedudukan saja, orang yang sederajat saja, dan seterusnya. Semakin banyak kita menghargai orang lain, maka semakin banyak pula orang yang akan menghormati kita.
Kretu panca yajna gawayenta panahura hutangta ring widhi.

Sahuren upadhyaya samasta hutang ira ri sang resiswara.

Wara gorawe sira sang abhyagata taman ayogya sambhraman.

Iti sasaneng tan pale-paleha ri dharma sang wiku.

\section{Artinya:}

Lima macam kurban suci harus senantiasa dilaksanakan sebagai penebus hutang kepada Sang Hyang Widhi Wasa. Semua hutang ilmu pengetahuan harus dibayarkan kepada orang-orang suci. Penghormatan yang baik harus diberikan kepada tamu yang datang dengan baikbaik, jangan sampai tidak menjammu para tamu tersebut. Inilah aturan untuk manusia yang tak boleh diabaikan terutama dalam hal kewajiban kepada sang Wiku. (Kakawin Niti Sastra IX.3)

Dalam ajaran agama Hindu di kenal lima macam kurban suci yang disebut sebagai Panca Yajna yang terdiri atas : Dewa Yajna (Kurban suci kepada Sang Hyang Widhi Wasa beserta para Dewa sebagai manifestasi-Nya); Bhuta Yajna (kurban suci kepada alam semesta); Manusa Yajna (kurban suci kepada sesame manusia); Pitr Yajna (kurban suci kepada para leluhur); dan Rsi Yajna (kurban suci kepada para rsi dan Guru-guru suci).

Kelima macam kurban suci tersebut pada dasaranya dilandasi dengan semangat untuk membayar tiga hutang yang disebut sebagai Tri Rna. Ketiga hutang ini terdiri atas : Dewa Rna (hutang kepada para Dewa atad hidup dan segala yang ada di alam semesta sebagai penunjang kehidupan ini); Pitr Rna (hutang kepada para leluhur dan orang tua yang telah melahirkan kita); dan Rsi Rna (hutang kepada para Rsi dan Guru-guru suci atas ilmu pengetahuan yang telah diajarkannya kepada umat manusia). Hutang kepada para guru suci tentu harus dibayarkan dalam bentuk daksina kepada beliau. Sementara itu hutang kepada para tamu sebagaimana telah disinggung di atas harus dibayar dengan cara penyambutan yang baik dan perjamuan yang diberikan kepadanya.

Yasa kirti karma kena denta tan elemelemeka sighranem. 
Gawayen tikang talaga tunggal amada magawe sumur satus.

Magawe ki talaga satus wilang ika pada pinra sakrama.

Mapadeki labhaning aputra sawiji gunamanta sadhana.

\section{Artinya:}

Jasa dan nama baik harus di tuntut dengan cepat; jangan sampai dipertangguhkan. Jasa orang yang mebikin sebuah telaga sama dengan membikin seratus buah sumur. Jasa orang yang membikin seratus telaga sama dengan melaksanakan kurban suci kepada sesame. Ini sama dengan keuntugan sesorang yang mempunya putera yang baik budinya sebagai alat untuk mencapai surga. (kakawin Niti Sastra IX.4).

Pupuh di atas juga dapat di temukan dalam kitab Slokantara 2 (6) sebagai berikut:

Kupasatad wai paraman saro'pi sarasatad wai paramo'pi yajnah.

Yajnasatad wai paramo 'pi putrah putrasatad wai paramam hi satyam.

\section{Artinya :}

Membuat sebuah telaga untuk umum itu lebih baik daripada menggali seratus sumur.Melakukan yajna (kurban suci) itu lebih tinggi mutunya daripada membuat seratus telaga. Mempunyai seorang anak yang suputra itu lebih berguna daripada melakukan seratus yajna. Dan menjadi manusia yang setia itu jauh lebih tinggi mutu dan gunanya daripada mempunyai seratus putra.

\section{PENUTUPAN}

Dari paparan di atas dapat di ketahui bahwa Pelaksanaan upacara Pitungdino kematian pada Paguyuban Majapahid Daerah Khusus Ibukota Jakarta, karena beranggotakan dari berbagai daerah jadi dalam pelaksanaanya upacara ini dilakukan sesuai tradisi daerah masing-masing. Pelaksanaan upacara pitungdino kematian ini bertujuan untuk proses terurainya unsur-unsur yang ada di dalam tubuh manusia untuk kembali lagi ke makrokosmos. Adapun prosesi dalam melaksanakan upacara pitungdino kematian ini berdasarkan adat Hindu di Jawa, yaitu sebagai berikut : 1) Masrahke pancen, 2). Enggehenggeh/kenduri. 3). Upacara Pitra Puja dengan melakukan persembahyangan dan kekidungan. Adapun banten yang dipersiapkan dalam upacara ini adalah; 1) ambengan, 2) Banten di meja depan pemangku yaitu Pejati, sego suci ulam sari, jajan pasar, jenang padang lepas, jenang pitara diissi kacang ijo dan suket glinting. 3). Pancen senthong tengah.

Relevansi pelaksanaan upacara Pitungdino kematian masyarakat Hindu di Jawa dengan umat Hindu di Bali, yaitu bahwa umat Hindu bali tidak ada prosesi upacara tujuh hari (pitungdino kematian) namun yang ada adalah upacara Pengabenan/Pelebon. Pelaksanaan upacara kematian di Jawa dan di Bali sama-sama mendewatakan para leluhur, dan menstanakan leluhur jika di bali di Rong Telu dan di Jawa di Senthong Tengah. Berikut adalah urutan upacara kematian menurut adat Hindu di Jawa adalah sebagai berikut : 1) hari kematian. 2). Brobosan. 3). Prosesi selametan kematian yaitu, ngesur tanah, nelung dino, mitung dino, metang puluhi, nyatus dino, pendak pisan, pendak pindo, nyewu, Pangentas. Sedangkan prosesi upacara kematian menurut adat umat Hindu di Bali adalah sebagai berikut: 1) saat menjelang kematian. 2). Setelah meninggal. 3). Sawa Prateka (perawatan jenasah). 4). Sawa Wadhana ( Pemakaman)/ atma Wedana (ngaben). 5). Dewa Pitra Pratista (Ngelinggihan Dewa Hyang). 6). Upacara Ngastiti yaitu dilakukan setelah 12 hari kematian.

Manfaat yang di dapat bagi keturunannya atas upacara pitungdino kematian, jika di laksanakan yaitu bertujuan untuk pengabdian dan rasa bhakti kita yang sangat tulus ikhlas kepada para leluhur kita, mengangkat serta menyempurnakan kedudukan arwah para leluhur kita di alam Swah Loka, dan memperhatikan kepentingan orang tua dalam mewujudkan rasa bhakti. Hal tersebut di laksanakan atas kesadaran bahwa sebagai keturunanya ia telah berhutang kepada Orang tua/leluhur. Manfaat yang didapat dari rangkaian upacara tersebut untuk anak, cucu dan keturunanya yaitu untuk kesejahteraan, dan perubahan alam sekitar secara skala dan niskala. 


\section{DAFTAR PUSTAKA}

Achmad, Sri wintala. 2018. Etika Jawa . Yogyakarta. : Araska

Atmaja, I Nengah Bawa. 1986. Metodologi penelitian. Jakarta : Gramedia

Arikunto, Suharsimi. 2002. Prosedur Penelitian Suatu Pendekatan Praktik (edisi V). Jakarta : Rhineka cipta.

Budi Cakepane gamabali, Bali Budaya, upakara dan Upacara Pitra yadnya. Cakepane.blogspot.com

Darmayasa. 2015. Bhagawad Gita (Nyanyian Tuhan). Yayasan Dharma Sthapanam: Denpasar.

Departemen Agama Propinsi Bali. 2006. Panca yadnya, Dewa Yadnya, Bhuta yadnya, Resi Yadnya,

Pitra Yadnya dan Manusa Yadnya. Bali. Kantor Wilayah Departemen Agama Propinsi Bali

Endraswara, Suwardi. 2018. Agama Jawa, Ajaran Amalan dan Asal Usul Kejawen (Edisi Revisi).

Yogyakarta : Narasi-Lembu Jawa.

Endraswara, Suwardi. 2018. Mistik Kejawen. Yogyakarta : Narasi.

Gulo. W. 2004. Metodologi Penelitian. Jakarta : Gramedia.

Jalinankata. 2015. Tehnik Analisis Data Kualitatif. Jalinkata's Blog, (akses tanggal 16 Agustus 2018).

Tersedia dalam URL: https://jalinankata.wordpress.com/2015/11/18/tehnik-analisisdata-kualitatif/.

Koentjaraningrat. 2014. Sejarah Teori Antropologi. Jakarta : Universitas Indonesia (UI-Pres).

Kajeng, I Nyoman, DKK. Sarasamuccaya. Jakarta. Pustaka Mitra Jaya

Layungkuning, Bendung.2018. Sangkan Paraning Dumadi. Yogyakarta: Narasi.

Nuridha Mega. 2013. Teori Hermeneutika. Dunia Mega (akses tanggal 27 November 2018). Tersedia dalam URL: https://nrdnr.wordpress.com/2013/10/01/teori-hermeneutika/.

Mantra, IB. 1997. Tata Susila Hindu Dharma. Denpasar : upada sastra, Surabaya : Paramitha.

Miswanto, 2015. Kakawin Nitisastra. Surabaya. Paramita.

Moleong, Lexi J. 2004. Metodologi Penelitian Kualitatif. Bandung : Pustaka Pelajar.

Oka Puspa, Anak Agung, 2009. Teologi Kematian Umat Hindu Di Bali (Kajian Teks Yama Purwana

Tattwa). Tesis Magister Pascasarjana Institut Hindu Dharma Negeri Denpasar.

Purwadi. 2005. Upacara Tradisional Jawa. Yogyakarta : Pustaka Pelajar.

Poerwadarminta, W.J.S. 1986. Kamus Umum Bahasa Indonesia, Jakarta : Gramedia.

Paguyuban Majapahit. 2013. Hasil Dharma Sabha VI. Jakarta

Palguna, IBM Dharma. 2018. Shastra Wangsa, Kamus Istilah Wangsa Bali, Pustaka, Pusaka, Manusia. Denpasar. Bali Wisdom.

Pandit, Bansi. 2006. Pemikiran Hindu, Pokok-Pokok Pikiran Agama Hindu dan Filsafat. Surabaya. Paramita.

Pudja, G. M.A. 2003. Manawa Dharmasastra (Manu Dharmasastra). Jakarta. Pustaka Mitra Jaya. G.MA, SH. 2005. Bhagawad Gita (Pancama Veda). Surabaya. Paramitha.

Pemerintah Propinsi Bali, 2002 Siwatattwa. Proyek Peningkatan sarana/Prasarana kehidupan Beragama. Denpasar.

Rudia Adiputra, Gede. 2003. Pengetahuan Dasar Agama Hindu. Jakarta : STAH Dharma Nusantara.

Radhakrishnan.S. 2008. Upanisad Upanisad Utama. Alih Bahasa Oleh Agus S. Mantik. Surabaya. Paramita.

Setiawan, I Ketut Oka. 2017. Bahan Kuliah Metodelogi Penelitian. Denpasar : Pragram Pascasarjana, UNHI.

Suripto, Adi. 2006. Nilai-nilai Hindu Dalam Budaya Jawa, Serpihan Yang tertinggal. Jakarta : Media Hindu.

Singgin Wikarman, I Nyoman. 2002. Ngaben (Upacara Dari Tingkat Sederhana Sampai Utama). Surabaya : Paramita.

Titib, I Made. 1998. Veda Sabda Suci Pedoman Praktis Kehidupan. Surabaya. Paramita.

Titib, I Made. 2004. Purana Sumber Ajaran Hindu Komprehensip. Surabaya : Paramita.

Usman, Husaini dan Purnomo Setiady Akbar. 1995. Metodologi Penelitian Sosial. Jakarta : Bumi Aksara.

Wiana, I Ketut, 2004. Makna Upacara Yadnya Dalam Agama Hindu II. Surabaya. Paramitha. 